\title{
Leczenie wewnq̨trznaczyniowe tętniaka rozwarstwiającego aorty piersiowo-brzusznej w przebiegu zespołu Marfana
} Endovascular treatment of thoracoabdominal dissected aneurysm in patient with Marfan syndrome

\author{
Wiktoria Kuczmik', Maria Stec', Agata Suleja', Wactaw Kuczmik² \\ 'Koło Naukowe Studenckiego Towarzystwa Naukowego przy Katedrze i Klinice Chirurgii Ogólnej, Naczyń, Angiologii i Flebologii \\ Śląskiego Uniwersytetu Medycznego w Katowicach (Student Research Group of Student Scientific Society at Department of General Surgery, \\ Vascular Surgery, Angiology and Phlebology, Medical University of Silesia, Katowice) \\ 2Katedra i Klinika Chirurgii Ogólnej, Naczyń, Angiologii i Flebologii Śląskiego Uniwersytetu Medycznego w Katowicach (Department of General Surgery, \\ Vascular Surgery, Angiology and Phlebology, Medical University of Silesia, Katowice)
}

\begin{abstract}
Streszczenie
U chorych z zespołem Marfana często obserwuje się schorzenia naczyniowe. Szczególnie dużym wyzwaniem dla współczesnej medycyny są rozwarstwienie i tętniak aorty. W niniejszej pracy przedstawiono przypadek chorego z rozwarstwiającym tętniakiem aorty piersiowo-brzusznej, z powodzeniem leczonego metodami wewnątrznaczyniowymi.
\end{abstract}

Słowa kluczowe: tętniak rozwarstwiający aorty piersiowo-brzuszny, zespół Marfana, stent-graft branchowy

Chirurgia Polska 2020, 22, 1-2, 29-34

Abstract

The vascular diseases are common in patients with Marfan syndrome. Especially, the dissection and aortic aneurysm are a great challenge for modern medicine. The case report presents successfully treated patient with dissected thoracoabdominal aortic aneurysm using endovascular methods.

Key words: dissected thoracoabdominal aortic aneurysm, Marfan syndrome, branched stent-graft

Chirurgia Polska 2020, 22, 1-2, 29-34

\section{Wstęp}

Zespół Marfana (MFS, Marfan syndrome) jest chorobą tkanki łącznej, dziedziczoną autosomalnie dominująco. Szacuje się, że występuje u 20-30 osób na 100000 mieszkańców Stanów Zjednoczonych i 6,5 osoby na 100000 mieszkańców Europy [1, 2]. Patogeneza MFS opiera się przede wszystkim na mutacji genu FBN1, kodującego białko fibrylinę 1. Dowiedziono, że MFS może powodować 3000 mutacji $F B N 1$. U 90\% chorych na na MFS mutacja jest ograniczona do regionu zajmowanego przez gen na chromosomie 15q21.1 [3]. Fibrylina to jedno z kluczowych białek macierzy zewnątrzkomórkowej biorące udział w regulacji elastogenezy oraz biodostępności transformującego czynnika wzrostu beta 1 [4]. Kluczowe konsekwencje mutacji są ujęte w klasyfikacji Ghent i dotyczą układów sercowo-naczyniowego, kostno-stawowego i narządu wzroku $[5,6]$. Są to przede wszystkim tętniaki lub 
rozwarstwienia aorty, podwichnięcia soczewki i charakterystyczne cechy morfologiczne, takie jak długie kończyny, szczupła budowa ciała, skolioza czy deformacja klatki piersiowej [7]. Mimo zróżnicowanej manifestacji MSF główną przyczyną zgonów u chorych pozostają powikłania dotyczące układu sercowo-naczyniowego [5]. Tętniaki aorty piersiowej (TAA, thoracic aortic aneurysm) należą do stosunkowo częstych i niebezpiecznych objawów MFS. Głównym czynnikiem predykcyjnym rozwarstwienia TAA u chorych z MFS pozostaje średnica opuszki aorty, przy zwiększonym ryzyku pęknięcia tętniaka w przypadku średnicy TAA > $50 \mathrm{~mm}$ [8].

\section{Opis przypadku}

Czterdziestoletni pacjent został w trybie ostrego dyżuru przyjęty do Kliniki Chirurgii Ogólnej, Naczyń, Angiologii i Flebologii SUM w Katowicach z powodu objawowego, bólowego tętniaka rozwarstwiającego aorty piersiowo-brzusznej. Zgłaszane przy przyjęciu bóle brzucha pojawiały się okresowo od 6 miesięcy. W przeszłości chory przebył kilka zabiegów chirurgicznych. W 2005 roku wykonano operację Bentalla - wszyto zastawkę aortalną z protezą aorty wstępującej z powodu ostrego rozwarstwienia aorty typu A. W 2017 roku implantowano stent-graft do dystalnej części łuku aorty i aorty zstępującej z zamknięciem lewej tętnicy podobojczykowej z powodu ostrego rozwarstwienia aorty typu B. Wcześniej u chorego rozpoznano MFS, wypadanie płatka zastawki mitralnej oraz nadciśnienie tętnicze.

Przy przyjęciu pacjent był przytomny, w dobrym kontakcie logicznym. Akcja serca była miarowa - około 50/min, tony serca nieco ściszone, prawidłowo akcentowane, bez szmerów patologicznych. Nie stwierdzono szmerów nad tętnicami ani obrzęków obwodowych. Tętno na kończynach dolnych w miejscach typowych było prawidłowe. Badanie palpacyjne brzucha wykazało obecność tętniącego guza śródbrzusza, bolesnego przy ucisku. W panelu badań laboratoryjnych nie stwierdzono odstępstw od normy.

W badaniu angiografii tomografii komputerowej aorty piersiowej i brzusznej uwidoczniono obraz przewlekłego rozwarstwienia aorty piersiowej zstępującej i brzusznej typu B, z poszerzeniem aorty maksymalnie do $61 \mathrm{~mm}$. Tętnice trzewne poza tętnicą nerkową prawą odchodziły od światła prawdziwego aorty. Rozwarstwienie aorty przebiegało do podziału aorty, a po stronie lewej przechodziło na tętnicę biodrową. W przebiegu rozwarstwienia widoczne były liczne fenestry, które łączyły światło rzekome ze światłem prawdziwym rozwarstwienia.

Konsultujący chorego przed zabiegiem kardiolog i kardiochirurg nie zakwalifikowali pacjenta do klasycznego zabiegu chirurgicznego z powodu związanego z nim bardzo dużego ryzyka, którego chory nie akceptował.

Wobec tego chory został zakwalifikowany do wieloetapowej rozległej interwencji hybrydowej — ta strategia miała zmniejszyć ryzyko zabiegu, zwłaszcza ryzyko niedokrwienia rdzenia kręgowego.
W pierwszym etapie, ze względu na objawowy charakter choroby, implantowano stent-grafty do aorty. Zabieg wykonano w znieczuleniu ogólnym. Chirurgicznie wyeksponowano prawą tętnicę udową wspólną oraz prawą tętnicę pachową. Prowadnik z prawej tętnicy udowej wyprowadzono na zewnątrz tętnicy pachowej, tworząc tzw. lejce trakcyjne, po których wprowadzono najpierw stent-graft piersiowy TX2, a następnie t-Branch, moduł rozwidlony, i uszczelniono stent-graftem prawą oś biodrową w tętnicy biodrowej wspólnej (ryc. 1A-1C). Następnie przy pomocy cewników angiograficznych wprowadzonych przez koszulkę umieszczoną w grafcie z dostępu pachowego przystąpiono do kaniulacji kolejnych naczyń trzewnych (pień trzewny, tętnica krezkowa górna oraz prawa i lewa tętnica nerkowa). Pień trzewny, tętnicę krezkową górną oraz lewą tętnicę nerkową połączono ze stent-graftem t-Branch za pomocą stent-graftów Bentley BeGraft (BGP) (ryc. 2A-2C). Pewną trudnością okazało się dotarcie do prawej tętnicy nerkowej poprzez fenestr $w$ błonie dzielącej światło prawdziwe i fałszywe, jako że ta tętnica odchodziła z światła fałszywego (ryc. 3). Po przejściu przez fenestr prowadnikiem poszerzono go cewnikami balonowymi o średnicach $10 \mathrm{~mm}$ i $12 \mathrm{~mm}$. Zakaniulowano prawą tętnicę nerkową i implantowano stent-graft VIABAHN $6 \times 100 \mathrm{~mm}$, dodatkowo mocując go za pomocą stentu samorozprężalnego (ryc. 4A, 4B). Ze względu na protekcję ukrwienia rdzenia kręgowego odstąpiono od jednoczasowej implantacji stent-graftu do lewej tętnicy biodrowej (ryc. 5).

W drugim etapie wykonano chirurgicznie przęsło szyjno-podobojczykowe po stronie lewej, aby uniknąć podkradania przez dużą drożną tętnicę kręgową lewą przy zamkniętej tętnicy podobojczykowej przez wcześniej implantowany stent-graft piersiowy.

W trzecim etapie natomiast zamknięto lewą oś biodrową stosownym stent-graftem.

\section{Dyskusja}

Przypadki chorych z tętniakami lub rozwarstwieniem aorty piersiowo-brzusznej oraz MFS stanowią ogromne wyzwanie dla współczesnej medycyny. Standardowo są oni leczeni metodami chirurgicznymi z wykorzystaniem krążenia pozaustrojowego [9], które w nielicznych ośrodkach o dużym doświadczeniu stosuje się, uzyskując relatywnie dobre wyniki, jednak i tam odsetek powikłań jest zauważalny. Jakkolwiek chorzy są kwalifikowani do leczenia zabiegowego w relatywnie młodym wieku, to jednak często występują u nich liczne czynniki ryzyka, związane najczęściej ze schorzeniami układu sercowo-naczyniowego. Wśród powikłań okołooperacyjnych poza śmiertelnością na szczególną uwagę zasługuje niedowład, a nawet porażenie kończyn dolnych w wyniku niedokrwienia rdzenia kręgowego, do którego dochodzi najczęściej do 3. dnia po zabiegu i które występuje z częstością 4-31\% [10]. W sytuacji, gdy z powodu wysokiego ryzyka nie można wykonać 

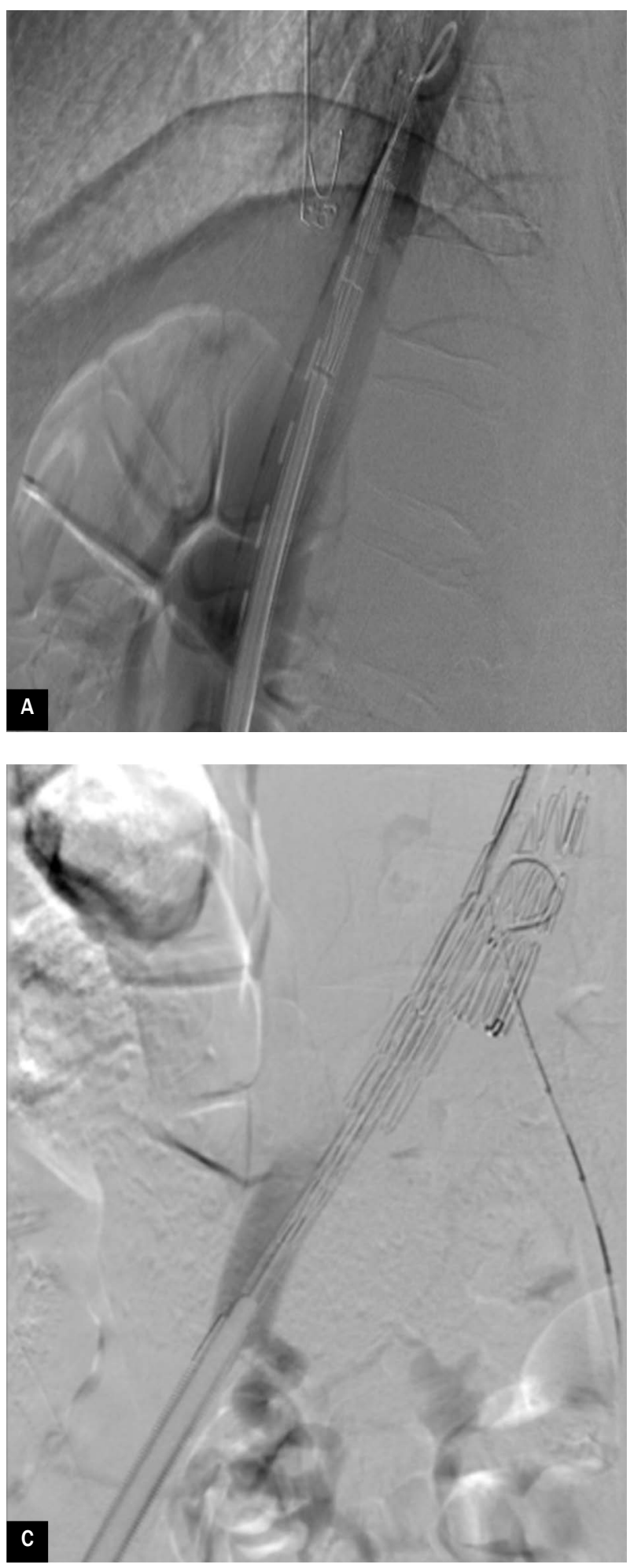

zabiegu chirurgicznego lub nie jest on akceptowany przez chorego, obecnie coraz częściej rozważa się wykorzystanie metod leczenia wewnątrznaczyniowego bądź hybrydowego [11]. Postęp technologiczny umożliwia coraz skuteczniejsze leczenie chorych z rozległymi chorobami aorty piersiowo-brzusznej. Jednak zwłaszcza u chorych z MFS wyniki leczenia są ciągle nieza-

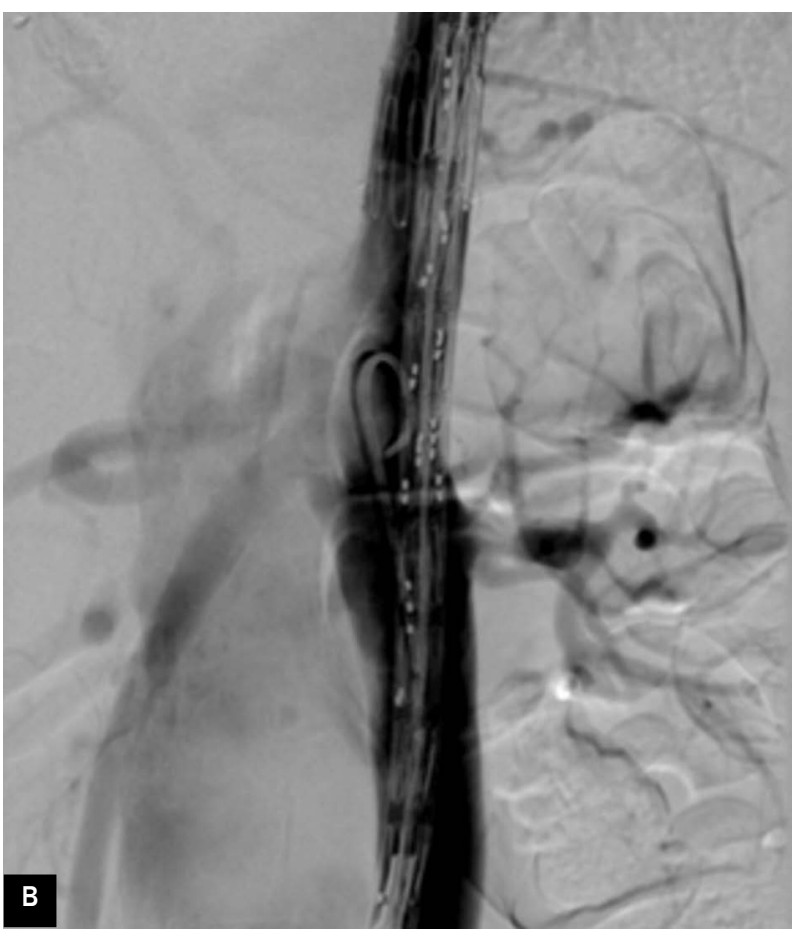

Rycina 1. A. Implantacja stent-graftu piersiowego; B. Implantacja stent-graftu branchowego; C. Implantacja stentgraftów brzusznego rozwidlonego i uszczelniającego prawą oś biodrową

dowalające w obserwacji odległej $[12,13]$. Obserwuje się przypadki rozszczelnienia stent-graftu w proksymalnej strefie lądowania z następowym przeciekiem typu I i szybko powiększającą się średnicą aorty. Inny zauważalny problem to wsteczne rozwarstwienie w łuku aorty sprowokowane przez proksymalny odcinek stent-graftu implantowany do dystalnej części łuku aorty. 

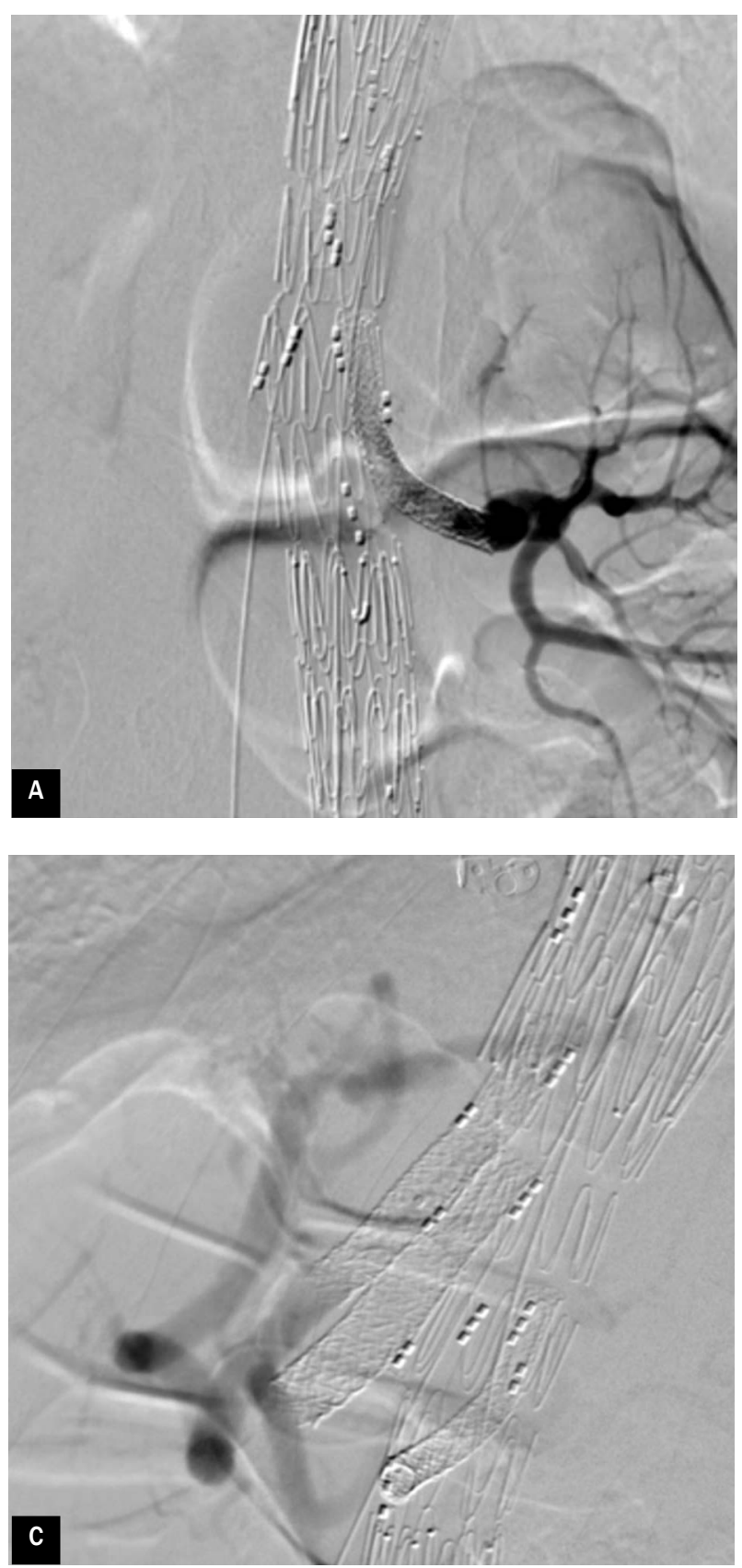

Przyczyną wymienionych powikłań są niewątpliwie niepełnowartościowe tkanki budujące ścianę aorty.

$Z$ tego względu łatwiej jest podjąć decyzję o leczeniu wewnątrznaczyniowym u chorych z dobrą, pewną proksymalną strefą lądowania, np. po wcześniejszej implantacji stent-graftu piersiowego pokrywającego entry rozwarstwienia lub chirurgicznej rekonstrukcji aorty protezą naczyniową. Jednak nawet wówczas nie unika się powikłań pod postacią niedokrwienia rdzenia kręgowego, a w konsekwencji paraplegii. W celu zmniejszenia ryzyka niedokrwienia stosuje się wiele metod, wśród których należy wymienić drenaż płynu mózgowo-rdzeniowego, utrzymywanie stałego ciśnienia tętniczego, unikanie istot-

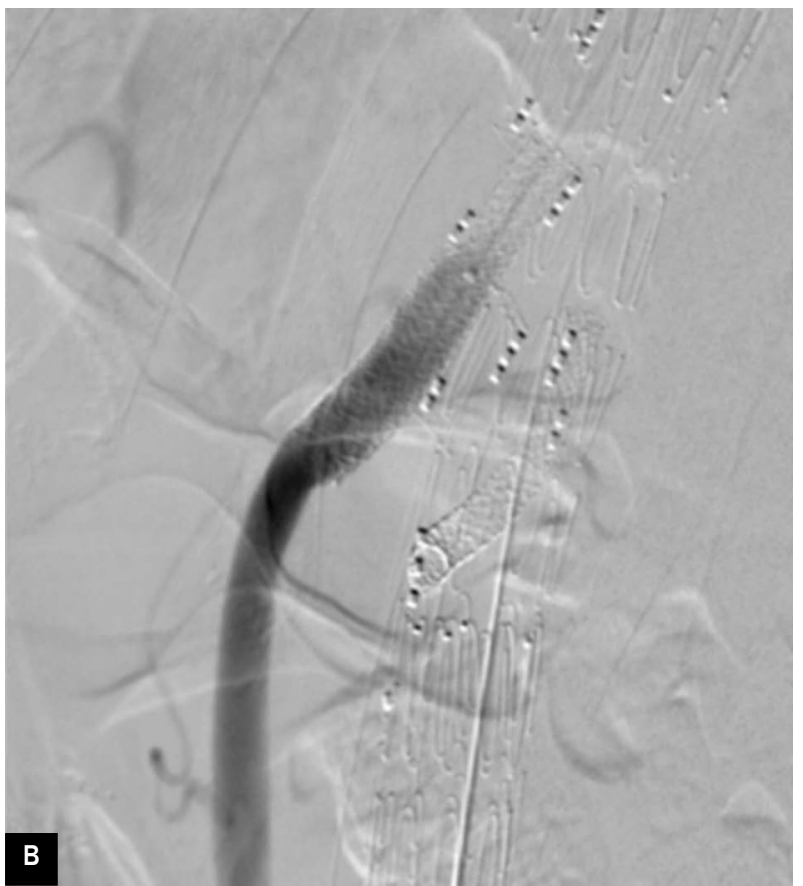

Rycina 2. A. Implantacja stent-graftu pomostowego do lewej tętnicy nerkowej; B. Implantacja stent-graftu pomostowego do tętnicy krezkowej górnej; C. Implantacja stent-graftu pomostowego do pnia trzewnego

krzepnięcia (ACT, activated clotting time) 250-320 podczas zabiegu. Poza wymienionymi metodami zmniejszenia ryzyka niedokrwienia rdzenia kręgowego na uwagę zasługuje stopniowe, etapowe wykonywanie zabiegu. Pamiętając o istotnym udziale w ukrwieniu rdzenia kręgowego tętnic międzyżebrowych i lędźwiowych, w opinii autorów powinno się je zamykać stopniowo. Można to osiągnąć poprzez implantację kolejnych segmentów stent-graftów w odstępach czasowych jak w prezentowanym przypadku, co jest możliwe w przypadku zabiegów planowych.

Innym sposobem na zachowanie czasowej perfuzji jest stosowanie konstrukcji stent-graftów branchowych z jedną lub dwiema dodatkowymi odnogami technicznymi 


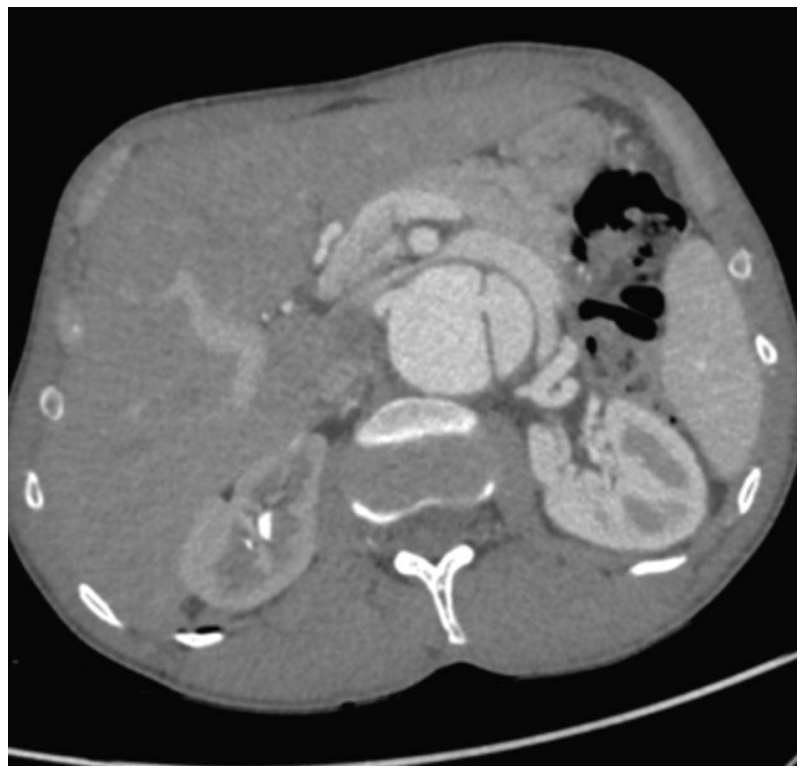

Rycina 3. Angiografia tomografii komputerowej - widoczny fenestr pomiędzy światłem prawdziwym i rzekomym aorty na poziomie prawej tętnicy nerkowej

czasowo perfundującymi worek tętniaka [14, 15], które po 2-4 tygodniach są zamykane definitywnie.

Reasumując, można stwierdzić, że leczenie chirurgiczne pacjentów ze schorzeniami aorty oraz MFS w ośrodku o dużej liczbie wykonywanych zabiegów wciąż pozostaje postępowaniem z wyboru. Jednak u chorych z dużym ryzykiem związanym z zabiegiem oraz pewną proksymalną strefą lądowania jako alternatywę można rozważać zabieg wewnątrznaczyniowy, optymalnie przeprowadzony etapami w celu zmniejszenia ryzyka paraplegii.

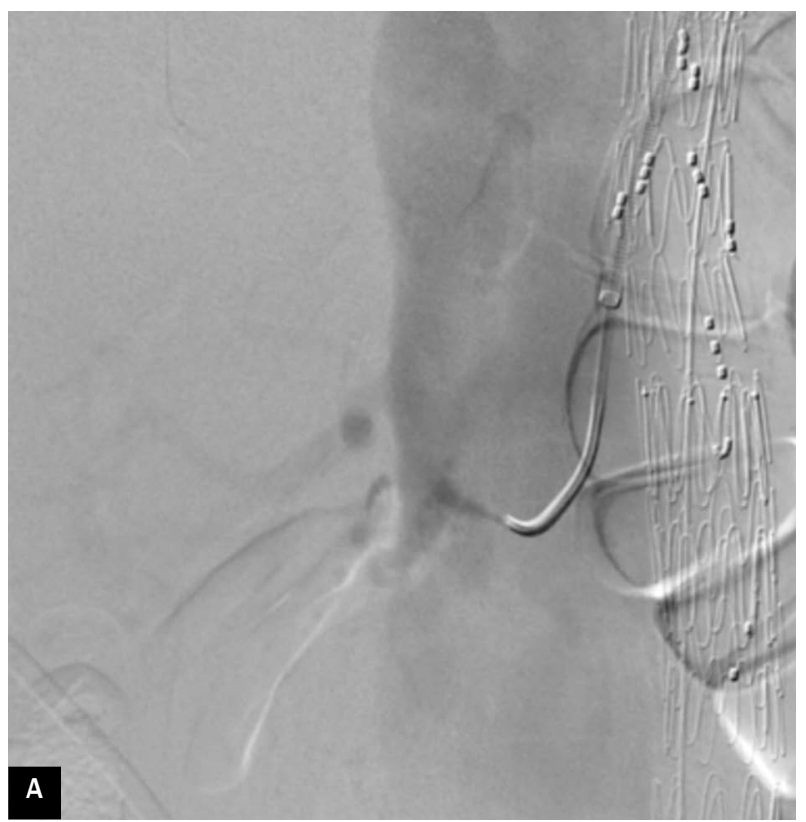

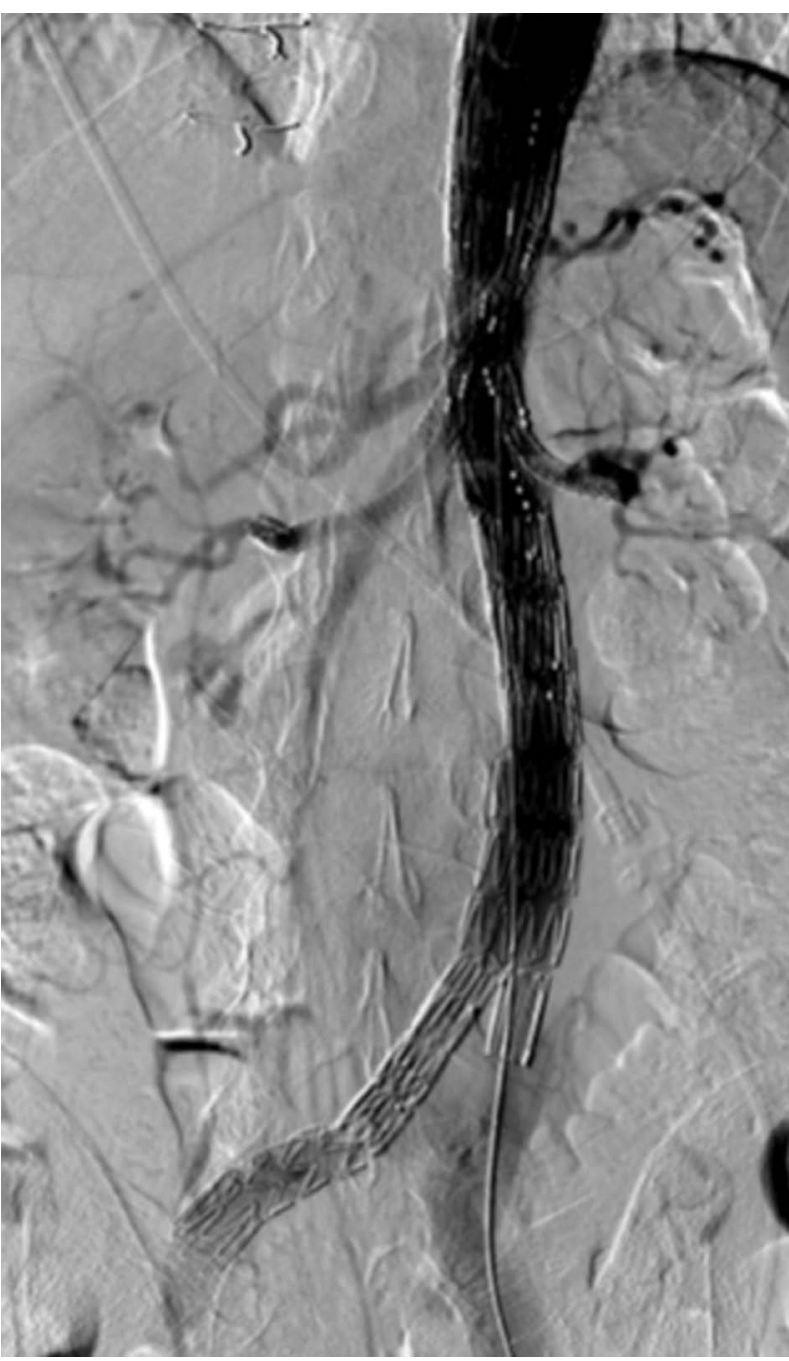

Rycina 5. Angiografia końcowa pierwszego etapu zabiegu z widoczną niezamkniętą osią biodrową lewą — protekcja ukrwienia rdzenia kręgowego

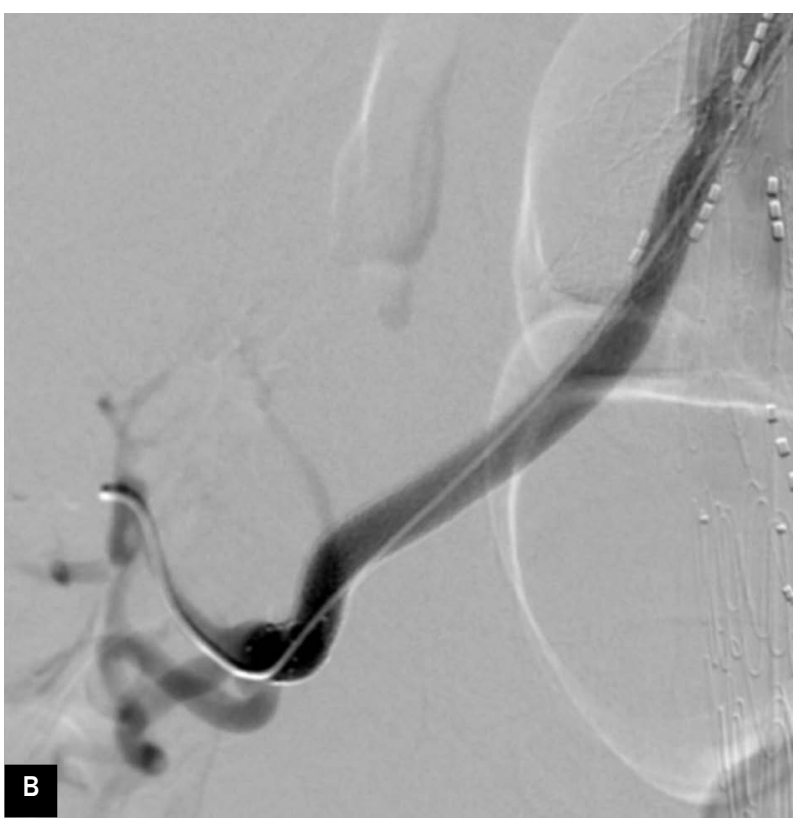

Rycina 4. A. Cewnikowanie prawej tętnicy nerkowej; B. Implantacja stent-graftu i stentu samorozprężalnego pomostowego do prawej tętnicy nerkowej 


\section{Piśmiennictwo}

1. Gatzoulis MA, Webb GD, Daubeney PEF. Ed.: Diagnosis and Management of Adult Congenital Heart Disease. Elsevier Ltd. ; 2011.

2. Groth $\mathrm{KA}$, Hove $\mathrm{H}, \mathrm{Kyhl} \mathrm{K}$, et al. Prevalence, incidence, and age at diagnosis in Marfan Syndrome. Orphanet J Rare Dis. 2015; 10: 153, doi: 10.1186/s13023-015-0369-8, indexed in Pubmed: 26631233.

3. $\mathrm{Wu} Y$, Sun $\mathrm{H}, \mathrm{He} \mathrm{Y}$, et al. A novel intron mutation in FBN-1 gene identified in a pregnant woman with Marfan syndrome. Hereditas. 2021; 158(1): 6, doi: 10.1186/s41065-020-00170-w, indexed in Pubmed: 33407909.

4. Al-Mohamad $\mathrm{H}$, Stout $\mathrm{K}$, Bolling $\mathrm{T}$, et al. A Case of an Abdominal Aortic Dissection in a Hemodynamically Stable Marfan Syndrome Patient Presenting without Pain. Case Rep Cardiol. 2020; 2020: 1704150, doi: 10.1155/2020/1704150, indexed in Pubmed: 32158563.

5. Pepe G, Giusti B, Sticchi E, et al. Marfan syndrome: current perspectives. Appl Clin Genet. 2016; 9: 55-65, doi: 10.2147/TACG. S96233, indexed in Pubmed: 27274304.

6. Loeys BL, Dietz HC, Braverman AC, et al. The revised Ghent nosology for the Marfan syndrome. J Med Genet. 2010; 47(7): 476-485, doi: 10.1136/jmg.2009.072785, indexed in Pubmed: 20591885.

7. Ludzia M, Smreczyńska-Wierzbicka E, Werner B. Diagnostic and therapeutic considerations in patients with Marfan syndrome. Nowa Pediatria. 2018; 22: 27-31.

8. Baumgartner H, De Backer J, Baumgartner H, et al. ESC Scientific Document Group. 2020 ESC Guidelines for the management of adult congenital heart disease. Eur Heart J. 2021; 42(6): 563-645, doi: 10.1093/eurheartj/ehaa554, indexed in Pubmed: 32860028.
9. Mommertz G, Sigala F, Langer S, et al. Thoracoabdominal aortic aneurysm repair in patients with marfan syndrome. Eur J Vasc Endovasc Surg. 2008; 35(2): 181-186, doi: 10.1016/j. ejvs.2007.10.013, indexed in Pubmed: 18069021.

10. Spanos K, Kölbel T, Kubitz J, et al. Risk of spinal cord ischemia after fenestrated or branched endovascular repair of complex aortic aneurysms. J Vasc Surg. 2019; 69(2): 357-366, doi: 10.1016/j. jvs.2018.05.216.

11. Fleck $T$, Hutschala $D$, Tschernich $H$, et al. Stent graft placement of the thoracoabdominal aorta in a patient with Marfan syndrome. J Thorac Cardiovasc Surg. 2003; 125(6): 1541-1543, doi: 10.1016/ s0022-5223(02)73606-4.

12. Waterford SD, Moon MR. Stent grafting in Marfan syndrome? We are not convinced. J Thorac Cardiovasc Surg. 2018; 156(5): 1773-1775, doi: 10.1016/j.jtcvs.2018.06.028, indexed in Pubmed: 30054136.

13. Pellenc $Q$, Girault A, Roussel A, et al. Optimising Aortic Endovascular Repair in Patients with Marfan Syndrome. Eur J Vasc Endovasc Surg. 2020; 59(4): 577-585, doi: 10.1016/j.ejvs.2019.09.501, indexed in Pubmed: 31865029.

14. Harrison SC, Agu O, Harris PL, et al. Elective sac perfusion to reduce the risk of neurologic events following endovascular repair of thoracoabdominal aneurysms. J Vasc Surg. 2012; 55(4): 1202-1205, doi: 10.1016/j.jvs.2011.10.079, indexed in Pubmed: 22305272.

15. Jayia P, Constantinou J, Hamilton $\mathrm{H}$, et al. Temporary Perfusion Branches to Decrease Spinal Cord Ischemia in the Endovascular Treatment of Thoraco-Abdominal Aortic Aneurysms. AORTA. 2018; 03(02): 56-60, doi: 10.12945/j.aorta.2015.14-045, indexed in Pubmed: 26798758.

\section{Adres do korespondencji:}

Wiktoria Kuczmik

Katedra i Klinika Chirurgii Ogólnej, Naczyń, Angiologii i Flebologii

Śląski Uniwersytet Medyczny

ul. Ziołowa 45/47, 40-635 Katowice

e-mail: wikikuczmik@interia.pl

Praca wpłynęła do Redakcii: $14.12 .2020 \mathrm{r}$. 